\title{
Ragweed Pollen Allergy: Burden, Characteristics, and Management of an Imported Allergen Source in Europe
}

\author{
Kuan-Wei Chen ${ }^{a, b}$ Laura Marusciac ${ }^{a, c}$ Paul Tudor Tamas ${ }^{a, c}$ Rudolf Valenta ${ }^{b}$ \\ Carmen Panaitescu $\mathrm{u}^{\mathrm{a}, \mathrm{c}}$ \\ a OncoGen Center, Pius Brinzeu County Clinical Emergency Hospital, Timisoara, Romania; ${ }^{b}$ Division of \\ Immunopathology, Department of Pathophysiology and Allergy Research, Medical University of Vienna, Vienna, \\ Austria; ' Victor Babes University of Medicine and Pharmacy, Timisoara, Romania
}

\section{Keywords}

Aeroallergen · Allergens · Allergy · Environmental factors · Immunotherapy $\cdot$ Ragweed pollen

\begin{abstract}
Ambrosia artemisiifolia, also known as common or short ragweed, is an invasive annual flowering herbaceous plant that has its origin in North America. Nowadays, ragweed can be found in many areas worldwide. Ragweed pollen is known for its high potential to cause type I allergic reactions in late summer and autumn and represents a major health problem in America and several countries in Europe. Climate change and urbanization, as well as long distance transport capacity, enhance the spread of ragweed pollen. Therefore ragweed is becoming domestic in non-invaded areas which in turn will increase the sensitization rate. So far 11 ragweed allergens have been described and, according to IgE reactivity, Amb a 1 and Amb a 11 seem to be major allergens. Sensitization rates of the other allergens vary between 10 and $50 \%$. Most of the allergens have already been recombinantly produced, but most of them have not been characterized regarding their allergenic activity, therefore no conclusion on the clinical relevance of all the allergens can be made, which is important and necessary for an accurate diagnosis. Phar-
\end{abstract}

macotherapy is the most common treatment for ragweed pollen allergy but fails to impact on the course of allergy. Allergen-specific immunotherapy (AIT) is the only causative and disease-modifying treatment of allergy with long-lasting effects, but currently it is based on the administration of ragweed pollen extract or Amb a 1 only. In order to improve ragweed pollen AIT, new strategies are required with higher efficacy and safety.

(c) 2018 S. Karger AG, Basel

\section{Introduction}

Ambrosia (ragweed) is an invasive annual flowering herbaceous plant from the family Asteraceae which originated from North America. About 40 species are known and Ambrosia artemisiifolia (common or short ragweed) and $A$. trifida (giant ragweed) are the most common species [1]. Among all Ambrosia species, A. artemisiifolia is the most prominent and invasive, being a major cause of allergy in late summer worldwide. The plant is characterized by a bushy-branched stem with pinnately lobed leaves (Fig. 1).

Edited by: W. Thomas, Perth, WA.

\section{KARGER}

(c) 2018 S. Karger AG, Basel

E-Mail karger@karger.com

www.karger.com/iaa
Correspondence to: Dr. Kuan-Wei Chen

Center for Gene and Cellular Therapies in the Treatment of Cancer - OncoGen Center Pius Brinzeu County Clinical Emergency Hospital

Bd. Liviu Rebreanu, 156, RO-300736 Timisoara (Romania)

E-Mail kuanwei.chen.2017@gmail.com 

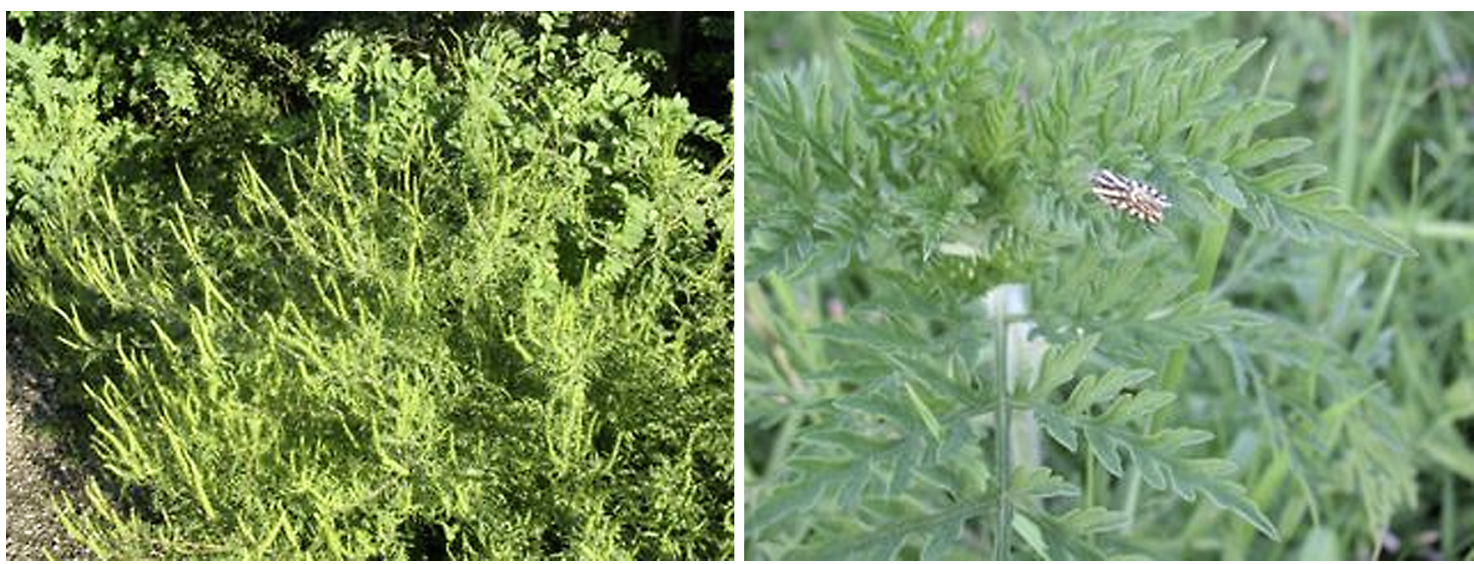

Fig. 1. Appearance of A. artemisiifolia. The height of the plant varies from $10 \mathrm{~cm}$ to $2.5 \mathrm{~m}$ according to environmental conditions. Stems are sparsely to densely pubescent with relatively long hairs. The pinnately lobed leaves are opposite towards the stem base, but alternate towards the stem tip.

In Europe, the first observation of A. artemisiifolia was in the mid of the 19th century [2] but an explosive expansion of ragweed occurred after 1900 due to the import of contaminated grains and seeds from North America, and this invasion event is still ongoing [1].

The most invaded areas with $A$. artemisiifolia and therefore the most important sources of ragweed pollen in Europe can be found in a few particular areas, which are the Pannonian Plain, especially Hungary and neighboring countries such as Romania, the Rhône Valley in France, parts of northern Italy and, just recently reported, Ukraine [3-7]. Beside North America and Europe, ragweed plants can also be found on other continents, including Asia, Australia, Africa, and South America [1, 8], which confirms the huge invasive ability of ragweed (Fig. 2).

In North America, ragweed has long been recognized as a major health problem. Allergic rhinitis and asthma are the main allergic diseases that have been associated with exposure to ragweed pollen, while skin allergic reactions are less common. In the 1930s ragweed was identified as the major cause of hay fever and asthma, and in the 1940 s the first eradication program was initiated for ragweed using herbicide [9]. Currently, the sensitization rates against ragweed pollen in the USA range between 15 and $26 \%$ of the common population $[10,11]$. In Europe, one of the first reports about ragweed pollen sensitization was published in the 1980s $[12,13]$. The sensitization rates among atopic patients can vary tremendously depending on the country. Sensitization rates of 60,47 , and $70 \%$ could be observed in Hungary [14], France, mainly the Rhône Valley [15], and in northern Italy [16], respectively. In other parts of Europe, such as Spain or the UK, no significant ragweed sensitization could be determined [17]. The situation in Asia seems to be different than in America and Europe. Although the ragweed plant is also now established in Japan, South Korea, and certain parts of China $[1,18]$, the sensitization rate seems to be low, at around 5\% [18-20].

Ragweed pollen allergy represents a major health issue and this may be due to some characteristics of the ragweed plant or pollen. One main characteristic is the high pollen production of the ragweed plant and the allergenic potency of the ragweed pollen itself. One single ragweed plant can release up to one billion pollen grains per season [21]. Studies have shown that high pollen exposure or the increase of pollen counts over a certain period of time leads to a strong increase of the sensitization rate and the occurrence of symptoms $[13,16]$. It is important to underline that even low exposure, meaning as little as 10 pollen grains per cubic meter of air, can trigger an allergic reaction $[22,23]$. The diameter of a ragweed pollen grain is only $15-25 \mu \mathrm{m}$ and the pollen surface is covered in short spines (Fig. 3). Ragweed pollen grains can be transported several hundreds to thousands of kilometers by air and can cause allergy symptoms in areas where the ragweed plant is not widespread $[6,24,25]$. In Denmark for instance, the occurrence of ragweed is moderate compared to Hungary, but sometimes peaks in pollen counts can be observed. Investigation has revealed that this additional pollen load had its origin in Ukraine and Romania, which are more than 1,000 kilometers away [26]. 


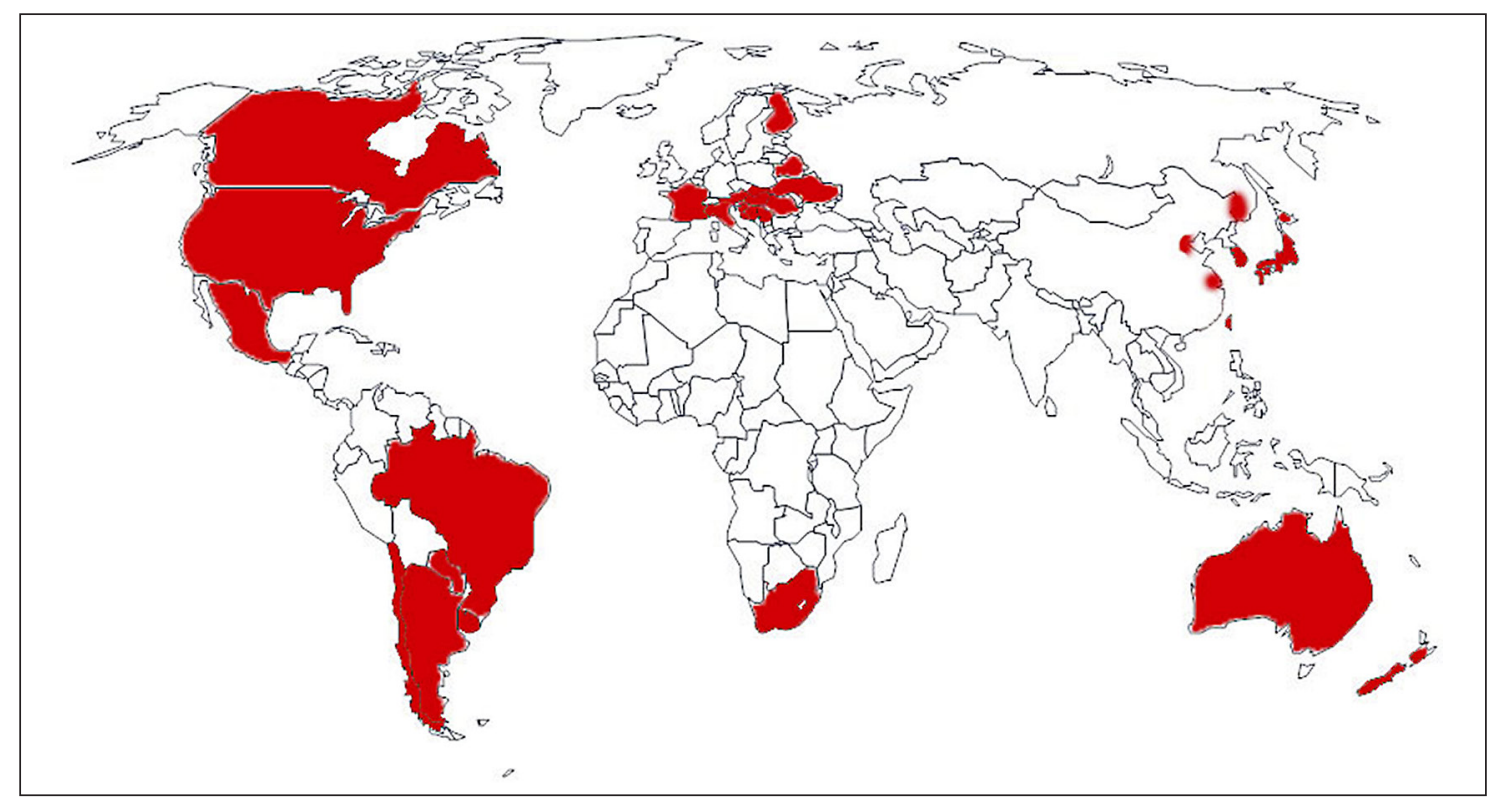

Fig. 2. Worldwide distribution of ragweed. Ragweed occurrence has been reported in different countries (red) in North America (Canada, the USA, Mexico), South America (Brazil, Uruguay, Paraguay, Argentina, Chile), Europe (Hungary and neighboring countries, Italy, France, Finland), Africa (South Africa), Asia (Japan, South Korea, China), Australia and New Zealand.

It has been suggested that de novo sensitization in adults is quite frequent $[16,27]$ and ragweed pollen induces asthma much more frequently than other pollens [28]. For example, $23.7 \%$ of sensitized ragweed pollenallergic patients showed asthma symptoms [14], another indicator for the allergenic potency of ragweed. The high sensitization rates and high percentage of asthma incidences may be explained by some contents in the ragweed pollen grains, such as a high concentration of NADPH oxidase and/or serine and cysteine proteases [29-31].

Environmental factors such as temperature and $\mathrm{CO}_{2}$ concentrations have great influences on pollen production and therefore on the allergen amount [32-34]. These two environmental factors are increasing due to climate change and urbanization. Prediction models indicate that ragweed will be widely spread and become domestic in large parts of Europe [3, 35, 36].

Due to their high prevalence and severe symptoms, ragweed pollen-induced allergic rhinitis and asthma may significantly affect quality of life, with an impact on attendance and performance at school or the workplace, leading to considerable healthcare costs and a high economic burden. In contrast to the current situation, ragweed pollen allergy will become a significant health issue in Europe which will not be restricted to only particular areas.

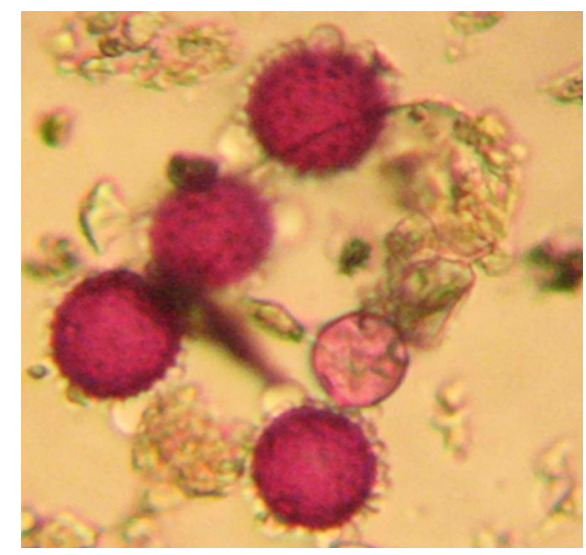

Fig. 3. A artemisiifolia pollen. Ambrosia pollen dyed with fuchsine (red) and visualized on an Optika B500 microscope at $\times 400$ magnification.

\section{Molecular Characterization of Ragweed Pollen Allergens}

Ragweed pollen allergens were studied for over half a century, with changing nomenclature over time, and still new allergens are being identified. There are currently 11 ragweed pollen allergens included in the IUIS database 
Table 1. Synoptic presentation of IUIS-recognized ragweed allergens [18, 38, 44, 52, 53, 74]

\begin{tabular}{|c|c|c|c|}
\hline Allergen & $\begin{array}{l}\text { IgE sensitization } \\
\text { rate }\end{array}$ & $\begin{array}{l}\mathrm{MW} \\
\mathrm{kDa}\end{array}$ & Description \\
\hline Amb a 1 & $90-95 \%$ & 38 & Pectate-lyase (enzyme), with 5 main isoforms, cross-reactive with Art v 6 \\
\hline Amb a 2 & \multicolumn{3}{|c|}{ Regrouped as Amb a 1.05 isoform } \\
\hline Amb a 3 & $30-50 \%$ & 11 & Plastocyanin (copper-binding protein) \\
\hline Amb a 4 & $20-40 \%$ & 30 & Defensin, cross-reactive with Art v 1 \\
\hline Amb a 7 & $15-20 \%$ & 12 & Plastocyanin (copper-binding protein), partly known sequence \\
\hline Amb a 8 & $20-35 \%$ & 14 & Profilin, important panallergen \\
\hline Amb a 9 & $10-15 \%$ & 10 & Polcalcin, with 2 EF-hand domains (Bet v 4-like), panallergen \\
\hline Amb a 10 & $10-15 \%$ & 18 & Polcalcin, with 3 EF-hand domains, panallergen \\
\hline Amb a 11 & $50-66 \%$ & 37 & Cystein-protease (enzyme), more than potential 20 isoforms and glycoforms \\
\hline Amb a 12 & $41-68 \%$ & 48 & Enolase \\
\hline
\end{tabular}

(www.allergen.org). Among these, 2 are described as major allergens, while the others are considered as minor allergens (Table 1) [37].

\section{Major Ragweed Pollen Allergens}

$A m b$ a 1 is a major allergen belonging to the pectate lyase protein family. Such enzymes are important for pollen growth by degrading pectines [38]. More than $90 \%$ of ragweed-allergic patients are sensitized to this major allergen [39]. Furthermore, Amb a 1 is an acidic non-glycosylated protein with 397 amino acids (AA) and has a molecular weight of approximately $38 \mathrm{kDa}$ [40]. Disulfide bonds can be located between C54-C71 and C211-C235, and potentially between C391 and C397 [41].

Currently, $5 \mathrm{Amb}$ a 1 isoforms are described in the WHO/IUIS allergen nomenclature database [37] with identities between 63 and $86 \%$ (see online suppl. Table S1a; see www.karger.com/doi/10.1159/000487997 for all online suppl. material). Immunological characterization of these 5 isoforms revealed different IgE-binding capacities, indicating that Amb a 1.01 has the highest allergenic activity [42].

No structural data such as X-ray crystallography are available for Amb a 1, but a homology model based on the crystal structure of the major cedar pollen allergen Jun a 1 (Juniperus ashei) indicates a core structure consisting primarily of a parallel beta-helix [41, 43] (Fig. 4). During purification, Amb a 1 can be proteolytically cleaved into 2 units, a $26-\mathrm{kDa}$ alpha (AA $181-396$ ) and a $12-\mathrm{kDa}$ beta (AA 26-180) subchain with different humoral (IgE) and cellular (T-cell) reactivity in sensitized individuals [40].
The alpha-subchain showed reduced IgE reactivity but comparable T-cell reactivity with the native allergen, whereas the beta-subchain showed a comparable IgE reactivity but reduced T-cell reactivity [41].

The expression of Amb a 1.01, 1.02, and 1.03 isoallergens could be upregulated under certain environmental situations, such as elevated $\mathrm{CO}_{2}$ or drought stress, which has been shown in greenhouse experiments [38]. Also, environmental factors such as temperature, humidity, and light had a significant influence on Amb a 1 content [32]. Another study revealed that fumigation of ragweed plant with a mixture of elevated $\mathrm{NO}_{2}$ (approx. 90\%) and NO increased the Amb a 1 allergen expression at least 1.5fold. This may explain why pollen collected in polluted areas has a higher allergenicity [44].

Amb a 1 shows a sequence homology of $58 \%$ with the mugwort allergen Art v 6 (see online suppl. Table S1a). Furthermore, Amb a 1 shares some sequence homology with allergens from the Cupressaceae family, such as Cry j 1 (Japanese cedar), Jun a 1 (mountain cedar), Cup a 1 (Arizona cypress), which ranges between 44 and $45 \%$. Amb a 1 shares the highest sequence homology (67.8\%) with the pectate lyase from Helianthus annuus (sunflower; see online suppl. Table S1a). Nevertheless, sunflower sensitization is rare, which may be due to the characteristics of sunflower pollen. Sunflower pollen is larger than ragweed pollen and therefore its wind dispersion is very limited. Exposure to sunflower pollen occurs only locally. Still, the exposed population, especially agricultural workers, can become sensitized to sunflower pollen and reach a sensitization rate of about $20 \%[45,46]$.

A comparison between Amb a 1 and the closely related weed allergen Art v 6 revealed that both allergens are 


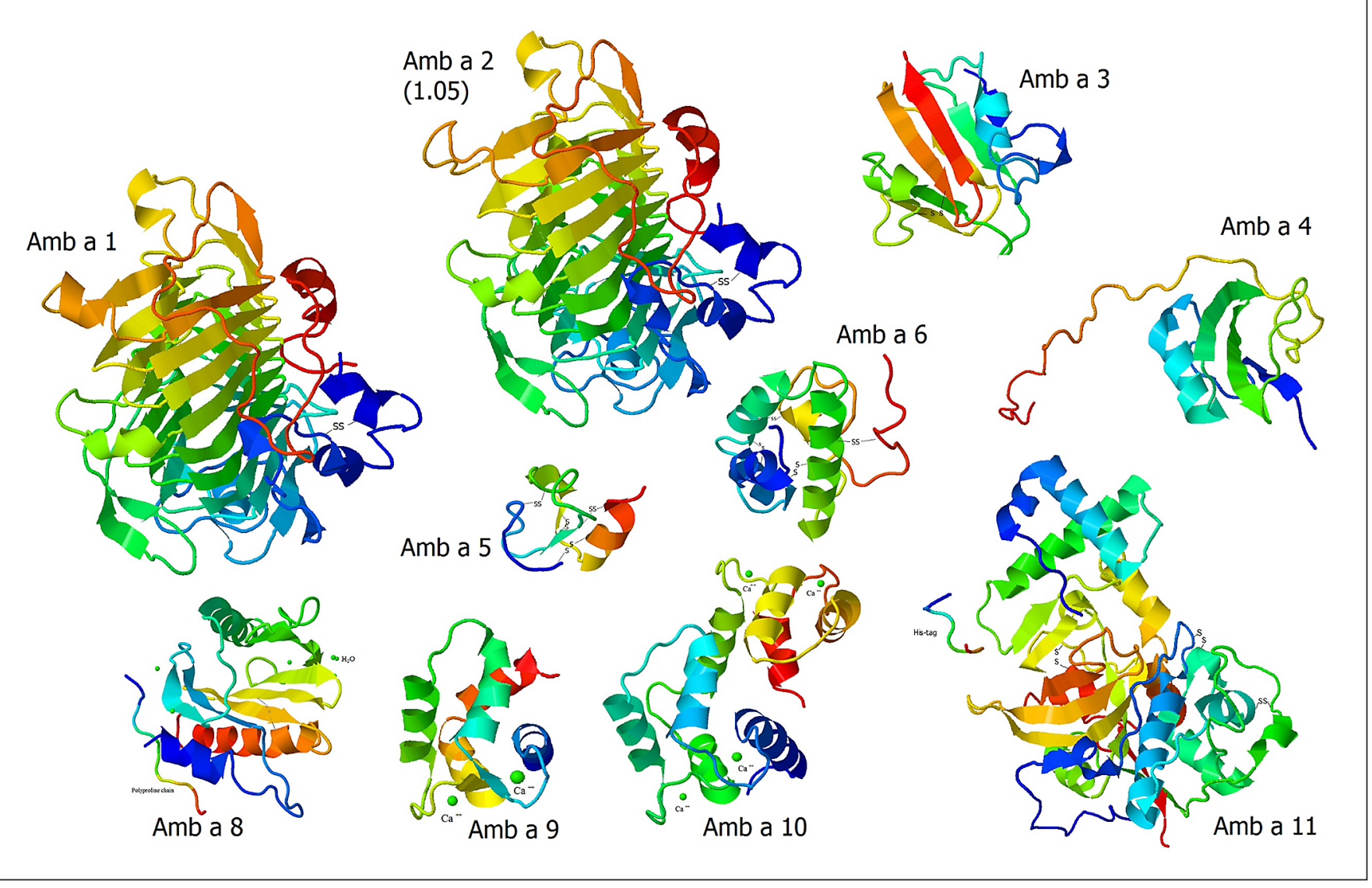

Fig. 4. Structure of ragweed allergens. Ribbon representations of ragweed allergen models were generated by the SWISS-MODEL online tool (https://swissmodel.expasy.org/) using similarity with known structures. Jmol software was used to display the structure in a color gradient, indicating the $\mathrm{N}$-terminal in red and the $\mathrm{C}$ terminal in blue. Amb a 8 and 11 structures were determined directly by X-ray crystallography. Amb a 7 is missing because no full sequence is available. cross-reactive [47], but Amb a 1 possesses more IgE epitopes and is a better T-cell stimulant [48]. Another study investigating the cross-reactivity between $\mathrm{Amb}$ a 1 and homolog pectate lyase allergens from the botanically unrelated Cupressaceae family (Cry j 1, Jun a 1, and Cup a 1) revealed no significant cross-reactivity between these 2 families [18].

Peripheral blood mononuclear cells from ragweed pollen-allergic individuals were used to map T-cell epitopes and 6 dominant epitopes were identified at position AA176-191, AA200-215, AA280-295, AA304-319, AA320-335, and AA344-359 [49]. These findings may be useful for new immunotherapy strategies.

Amb a 1 (isoform Amb a 1.0301) has been expressed in recombinant form, first in Escherichia coli as Histagged protein. However, this recombinant allergen showed a very low IgE binding activity, maybe due to mis-

Ragweed Pollen Allergy: An Increasing Health Issue in Europe folding [41, 50]. Recently, Amb a 1.0301 has been expressed in Pichia pastoris with an IgE reactivity comparable with the native form [42].

Amb a 2, designated now as Amb a 1.05, is an Amb a 1 isoform showing $67 \%$ sequence identity (see online suppl. Table S1a) with Amb a 1.01. Amb a 2 is an allergen with $397 \mathrm{AA}$ and has a molecular weight of $38 \mathrm{kDa}$ [51].

Recently, Amb a 11, a cysteine protease, has been suggested as a novel major allergen with a sensitization rate of up to $66 \%$ [52]. This allergen has a molecular weight of approximately $37 \mathrm{kDa}$ in its mature form with 386 AA. Since Amb a 1 has a nearly identical size, it can only be detected and visualized on a 2D blot analysis. There is an N-glycosylation site at the 19th position with variable glycan ligands and 3 disulfide bridges stabilizing the protein [52]. Detailed mass spectrometry analysis of purified natural Amb a 11 revealed that more 
than 20 potential isoforms and glycoforms may exist [52].

The crystal structure of Amb a 11 was identified by using a recombinant proform. The structure of pro $\mathrm{rAmb}$ a 11 is typical of a C1A cysteine protease consisting of 6 alpha-helices and a beta-sheet formed from 6 antiparallel beta-strands in its mature form (Fig. 4) [53].

Regarding the allergenic potency of the molecule, sensitization with mature $\mathrm{rAmb}$ a 11 in mice induced strong allergic inflammation after challenge with ragweed pollen extract. In detail, the mice showed airway hyperresponsiveness, high levels of eosinophils and innate lymphoid type 2 cells (ILC2) in bronchoalveolar lavage fluid, as well as Amb a 11-specific IgE and $\mathrm{IgG}_{1}$ responses after challenge with ragweed pollen extract. However, sensitization with pro-rAmb a 11 or E64-inhibited $\mathrm{rAmb}$ a 11 resulted in lower allergic responses [53]. These effects correlate with reports on cysteine protease allergen-induced disruption of airway epithelium, as well as with proteaseenhanced activation of immune cells and initiation of Th2-type inflammation [54].

Sequence alignment with other allergens showed that Amb a 11 shares homology with other major allergens belonging to the same protease family, such as Act $\mathrm{d} 1$ from kiwi fruit (36.9\%), Ana c 2 from pineapple (34.1\%), and Der f/Der p 1 from dust mites (27.3/23.5\%; see online suppl. Table S1i).

Comparing the IgE sensitization profile in 92 American and European patients revealed 4 distinct patterns, which are Amb a 1 alone (40\% of the patients), multiple allergens including the major allergens (15\%), mainly Amb a 1 and Amb a 11 (30\%), or mainly Amb a 11 (15\%) [52]. This indicates that Amb a 11 should also be included in diagnosis and treatment.

\section{Minor Ragweed Pollen Allergens}

Many minor allergens can be assigned to panallergens, which are proteins sharing highly homologous sequences, structures, and functions. These similarities can lead to IgE cross-reactions. Protein families, such as profilins, polcalcins, and non-specific lipid transfer proteins (nsLTP) are known panallergens and many minor ragweed allergens correspond to these families.

$\mathrm{Amb}$ a 8 belongs to the profilin family with a molecular weight of approximately $14 \mathrm{kDa}(133 \mathrm{AA})$ and 2 isoforms have been identified $[55,56]$. Profilins are small proteins which regulate actin polymerization and depolymerization during pollen growth [57]. Profilins have been discovered as highly cross-reactive allergens in birch $[58,59]$ and were identified as actin-binding proteins in plants soon thereafter [60]. The sensitization rate is approximately $26 \%$ in ragweed pollen-allergic patients [56].

The Amb a 8 molecule has a disulfide bond between C95 and C117, a poly-proline region and an actin binding site. Further characterization revealed the structure showing 2 terminal alpha-helices, 1 short alpha-helix, and a beta-hairpin that sandwich a central 5-stranded antiparallel beta-sheet [61] (Fig. 4).

In allergic patients, profilins could be responsible for cross-reactivity with other food and pollen allergens, such as Cor a 2 (hazelnut), Mal d 4 (apple), Dau c 4 (carrot), Mus a 1 (banana), Pru p 4 (peach), Hel a 2 (sunflower), Phl p 12 (timothy grass), Bet v 2 (birch), Ole e 2 (olive), Cyn d 12 (Bermuda grass), and with many other allergens. All these cross-reactive allergens showed a sequence identity of over $65 \%$ (see online suppl. Table S1c). In addition, Amb a 8.0101 shares $89.5 \%$ of its AA sequence with Art v 4.0101, displaying comparable cross-reactivity within the same family due to structural similarities between the 2 proteins [61]. There is a close relationship between ragweed and sunflower proteins, as the highest homology outside the species is recorded between ragweed and sunflower, mainly for profilin (94\% sequence homology, see online suppl. Table S1f) but also for pectate lyase $(68.4 \%$ sequence homology, see online suppl. Table $\mathrm{S} 1 \mathrm{a})$. The transcript for Amb a 8.1 was downregulated in elevated $\mathrm{CO}_{2}$ conditions in a greenhouse experiment [38].

Amb a 9 and Amb a 10 belong to polcalcins, a family of calcium-binding proteins (CBP) containing EF-hand domains. CBPs play an essential role in calcium signaling during pollen tube growth [62].

Amb a 9 has a molecular weight of $9 \mathrm{kDa}$ with a length of $82 \mathrm{AA}$ and Amb a 10 has a molecular weight of $18 \mathrm{kDa}$ with a length of $160 \mathrm{AA}$, and the sensitization rate in ragweed pollen-allergic patients is approximately $10-15 \%$ for both allergens $[56,63]$. Amb a 9 has 2 EF-hand domains and belongs to the Bet $\mathrm{v}$ 4-like polcalcins group, while Amb a 10 has 3 such domains. Structural analysis performed with circular dichroism revealed a primarily alpha-helical secondary structure (Fig. 4). Calcium binding may alter the conformation of the allergen significantly, which may then influence the IgE binding capacity [64]. The absence of calcium did not alter the structure significantly while calcium was necessary for IgE binding [56]. Sequence alignment analysis showed shared sequence homology with other allergens from the same protein family, such as Art v 5, Syr v 3, Bet v 4, and Ole e 
3 for Amb a 9 and for Amb a 10 similarity with Ole e 8, Cyn d 7, and Phl p 7 (see online suppl. Table S1g, h) and variable cross-reactivity with other polcalcins can be observed [56]. Expression of Amb a 9 and 10 was upregulated in drought stress and elevated $\mathrm{CO}_{2}$ conditions in a greenhouse experiment [38].

Amb a 6 is a basic $10-\mathrm{kDa}$ type I nsLTP with a sensitization rate of $21 \%$ among ragweed pollen-allergic patients [65]. This allergen is expressed as a promolecule with 188 AA residues including an $\mathrm{N}$-terminal $25 \mathrm{AA}$ signal peptide [66].

A structural model generated by the SWISS-MODEL online tool (https://swissmodel.expasy.org/) indicates that Amb a 6 contains 4 alpha-helices cross-linked with 4 disulfide bridges that stabilize a hydrophobic inner cavity (Fig. 4). Although nsLTPs are a family of panallergens commonly found in fruits and nuts, sequence homology of Amb a 6 with other nsLTPs is limited, indicated by an identity score of below $40 \%$ (see online suppl. Table S1e). However, cross-reactivity among pollen LTPs could not be observed and cross-reactivity between nsLTPs from foods and pollens is limited [67].

$\mathrm{Amb}$ a 3 is a highly basic protein belonging to the plastocyanin family. It has a single-copper ion-binding site, which is involved in the electron transport chain in plants. $\mathrm{Amb}$ a 3 has a molecular weight of approximately $11 \mathrm{kDa}$ (101 AA) and can be $\mathrm{N}$-glycosylated on position AA 41 and O-glycosilated on position AA 84 [68]. The sensitization rate has been reported to be between 30 and 50\% [69] classifying Amb a 3 as a minor allergen. Sequence homology analysis showed no homology with other allergens but some similarities with other plant proteins such as the sunflower, $H$. annuus (63\%; see online suppl. Table S1b).

$\mathrm{Amb}$ a 7 is another minor allergen belonging to the plastocyanin family. Not much is known about this allergen. In 1991, it was reported that Amb a 7 was isolated and purified from ragweed extract via chromatography methods. N-terminal sequencing of this approximate 12$\mathrm{kDa}$ protein revealed a partial sequence homology with a 96 residue cucumber "cusacyanin" (57\% identity) and a $15-20 \%$ IgE reactivity in ragweed pollen-allergic patients was determined [70].

Amb a 4 belongs to the defensin-like protein family with a molecular weight of approximately $30 \mathrm{kDa}$. Further characterization identified $\mathrm{Amb}$ a 4 as a glycoprotein with a proline-rich C-terminal region and 4 intramolecular disulfide bonds. A sensitization rate of 20-39\% among ragweed pollen-allergic patients was determined [71].

A structure model generated by the SWISS-MODEL online tool shows a molecule with an alpha-helix, 3 anti-

Ragweed Pollen Allergy: An Increasing

Health Issue in Europe parallel beta-strands, and a proline-rich region (Fig. 4). This structure composition seems to be characteristic for allergens belonging to this protein family [72].

Sequence alignment analysis showed high homology (over 60\%) between Amb a 4, Par h 1 (Parthenium hysterophorus, feverfew), and a defensin-like protein originated from $H$. annuus. Similarities with different species of Artemisia were between 50 and 54\% (see online suppl. Table S1c). This observation has also been made by other studies [71, 72].

Patients showing IgE reactivity to Amb a 4 often also react to Art v 1. Whether this reaction is due to crossreactivity or co-sensitization remains unclear $[71,72]$.

Amb a 5 is a small molecule with a molecular weight of $5 \mathrm{kDa}$ and is $45 \mathrm{AA}$ long [73,74]. The sensitization rate is reported to be around $10 \%$ [75]. Structural analysis of Amb a 5 revealed a molecule with a C-terminal alphahelix, a short stretch of triple stranded antiparallel betasheets and several loops. This structure is stabilized by 4 disulfide bonds [76] (Fig. 4). Sequence analysis showed that Amb a 5 only shares similarities with proteins from the same genus (see online suppl. Table S1d).

A very recently identified allergen mentioned in the IUIS database, Amb a 12, is an enolase with a molecular weight of approximately $48 \mathrm{kDa}$, with a homologous structure to Hev b 9 and a significant prevalence of $\operatorname{IgE}$ reactivity, reported as being from 41 to $68 \%$. A number of proteins with enolase activity and molecular weights from 42 to $51 \mathrm{kDa}$ have been identified as potential allergens in recent studies [37, 44, 77].

\section{Potential New Ragweed Allergens}

A study using transcriptomic and immunoproteomic techniques to screen for potential new allergens using 22 sera from ragweed pollen-allergic patients indicated a 68 and $41 \%$ sensitization rate to ragweed polygalacturonase (existing in 2 isoforms) and enolase, respectively. Seven novel candidate allergens are proposed, including the 2 already mentioned and a form of carbonic anhydrase, galactose-oxidase (2 isoforms), UDP-glucose pyrophosphorylase, GDP dissociation inhibitor, and pathogenesisrelated 17 (PR-17) protein. The last 2 were designated as the most promising candidates for new allergens. A number of plastocyanin-like proteins were also identified, with IgE reactivity between 10 and 20\% [77].

Another proposed minor allergen is Amb a CPI, a cysteine protease inhibitor present in ragweed pollen [78], with homology to other plant allergens found in Acti- 
nidia deliciosa [79]. Elevated ragweed plant exposure to ozone can induce a higher level of expression for Amb a $\mathrm{CPI}$ and for the major allergen Amb a 1, as was revealed by transcriptomic assays [80].

\section{Therapeutic Approaches in Ragweed Allergy}

There are no consistent data regarding the relationship between ragweed pollen exposure and the severity of allergic reactions. However, the treatment should be tailored in accordance with the level of symptoms, regardless of the level of exposure (lower or higher). There are 3 major therapeutic approaches for allergic rhinitis and asthma: (1) allergen avoidance and reduced exposure to triggers, (2) symptomatic medication, and (3) allergenspecific immunotherapy (AIT).

\section{Allergen Avoidance}

Allergen avoidance strategies can effectively improve allergic symptoms. However, unlike in food allergy, complete avoidance may be difficult to achieve, especially for pollen allergens. Exposure to pollen can be minimized by using air conditioners to filter the air, keeping windows closed, especially during the day, and reducing the time spent outdoors during peak pollen season. In order to inform people about pollen conditions, attempts have been made to develop regional specific pollen counts in the atmosphere or to create forecasting models [7].

The only feasible way to avoid ragweed pollen is to limit ragweed spread, which is currently an important challenge in Europe. Different methods, such as herbicides, mowing, weeding, competition vegetation, crop rotation, disking, grazing, milling and plowing, singeing, or mulching, have been employed with varying effectiveness in order to control ragweed expansion [81].

\section{Symptomatic Treatment Options}

Symptomatic treatment is widely used to manage ragweed pollen-induced allergic rhino-conjunctivitis. It mainly consists of oral non-sedating H1-antihistamines and intranasal glucocorticoids, according to the Allergic Rhinitis and Its Impact on Asthma (ARIA) guidelines (http://www.euforea.eu/about-us/aria.html). In addition, mast cell stabilizers, leukotriene antagonists, and anti-inflammatory eye drops can be taken. Combined ap- proaches with multiple therapeutic agents are frequently administered.

For ragweed pollen-induced allergic asthma, the main therapeutic classes are inhaled corticosteroids (ICS) and $\beta_{2}$-agonists. According to the Global Initiative for Asthma (GINA) guideline, patients with purely seasonal allergic asthma, such as ragweed pollen-induced allergic asthma, ICS should be taken as soon as symptoms appear, and continued for 4 weeks after the end of the pollen season [82].

Future therapeutic options, such as selective antagonists for $\mathrm{H} 3$ histamine, DP2 and leukotriene $\mathrm{B} 4$ receptors, or immunomodulators which target Toll-like receptors (TLRs), aim to ensure increased efficiency, easier administration, and fewer side effects [83-86]. Even though the effectiveness of symptomatic medication is certified by randomized controlled clinical trials, pharmacotherapy often cannot adequately control symptoms [87] and it may induce side effects. In the case of ragweed pollen allergy, symptom control can be reached in less than 50\% of the patients using conventional therapies [88]. Moreover, symptomatic treatment cannot impact the underlying immune mechanisms of allergy, and consequently cannot change the course of disease [89]. The pros and cons of common symptomatic medication and of AIT are listed in Table 2.

\section{Allergen-Specific Immunotherapy}

AIT is the only disease-modifying treatment, with long-lasting effects even after its discontinuation, and is able to stop the atopic march $[90,91]$. AIT is indicated for the treatment of moderate-to-severe intermittent or persistent symptoms of allergic rhinoconjunctivitis, especially in patients with a poor response to pharmacotherapy, according to the ARIA guidelines. Regarding asthma, the current ARIA, ICON (International Consensus on Allergic Immunotherapy), and GINA guidelines give AIT a conditional recommendation, due to moderate or low quality of evidence.

Ragweed pollen AIT has been in use for over 100 years. The first successful trial of ragweed pollen subcutaneous immunotherapy (SCIT) was conducted in 1913, and used aqueous ragweed pollen extracts [92]. Another study from 1935 showed that transfer of serum from patients who had received treatment with ragweed extract confer protection during the ragweed pollen season to immunotherapy-naive patients [93]. A study on sera from patients treated with ragweed extract for up to 20 years was con- 
Table 2. Pros and cons of common symptomatic medication versus AIT for allergic rhinitis

\begin{tabular}{lll}
\hline & Advantages & Disadvantages \\
\hline Antihistamines & Immediate effects & Somnolence (more for 1st generation) \\
& Good symptom control & Confusion (more for 1st generation) \\
& Long-lasting effects (up to 24 h) & Moodiness (more for 1st generation) \\
& & $\begin{array}{l}\text { Dizziness (more for 1st generation) } \\
\text { Xerostomia }\end{array}$ \\
\hline Glucocorticoids & Good symptom control & Late onset of action \\
& & Long period until reaching symptom control \\
& & Epistaxis \\
& & Nasal irritation \\
& & Systemic disorders (Cushing syndrome) \\
\hline Immunotherapy & The only disease-modifying treatment & Long duration of treatment \\
& & Possible immediate or delayed reactions \\
\hline
\end{tabular}

ducted in 1964, showing a progressive decline in the concentration of sensitizing antibodies [94]. The first doubleblind randomized clinical trial on the efficacy of a multiallergen mix for ragweed pollen allergy was conducted by Lowell and Franklin [95].

Allergen extract-based AIT is not yet widespread due to several reasons: the vaccination schedule may be inconvenient, requiring at least 3 years of therapy, the costs may be high, and there is always the risk of severe side effects. The main concerns of using natural allergen extracts are their quality, more precisely the presence of contaminants or undefined components that may promote allergic immune responses, and variable amounts of relevant allergens and thus differences in immunogenicity [96]. Analysis of different extracts used for the diagnosis and treatment of ragweed pollen allergy revealed a tremendous variation in allergen content and allergen concentration, which could significantly impact the treatment by reduced efficiency of such agents. The variation is underlined especially when measuring the relative potency of ragweed pollen extracts in Amb a 1 units, emphasizing the correlation between major allergen contents and the extract's biological potency [97].

The first improvement of ragweed AIT was the use of adjuvants (e.g., aluminum hydroxide, calcium phosphate, or tyrosine) and the chemical modification of extracts (allergoids), which lowered the risk of systemic side effects and enabled the faster achievement of the maintenance dose in comparison with aqueous extracts [98]. New adjuvants, such as monophosphoryl lipid A, the non-pyrogenic component of Salmonella minnesota LPS, combined with ragweed allergoid adsorbed to L-tyrosine, in order to boost its immunogenicity, are currently available $[99,100]$. Another approach of AIT improvement is the additional treatment with omalizumab, a monoclonal anti-IgE antibody [101], which is an off-label use [102]. Omalizumab blocks IgE binding to FceR1 on the surface of effector cells (e.g., mast cells, basophils) [103], limiting the effects of allergen exposure mediated by these cells. The rationale for combining AIT and omalizumab is based on their complementary action which can increase AIT safety. There are clinical data showing that omalizumab pretreatment can reduce the side effects of subcutaneous rush immunotherapy for ragweed pollen-induced allergic rhinitis [104].

Currently, the challenge to develop better products for AIT remains, in terms of safety, efficacy, and cost-benefit ratio, in order to increase patient compliance, without interfering with the immunomodulatory activity. The strategies addressing this challenge include the introduction of other administration routes, shorter build-up schedules of administration, and new forms of treatment based on recombinant allergens, hypoallergenic allergen derivatives, and allergen-derived peptides [105-107].

While SCIT has traditionally been used for administration of AIT, sublingual immunotherapy (SLIT) has been gaining interest, since its introduction in 1986, due to the potentially lower risk of severe side effects [108]. Most SLIT products currently on the market are solutions, but SLIT tablets entered the North American market in 2014, and are being prepared for approval in Europe. Several randomized, controlled clinical trials have been conducted in order to investigate SLIT efficacy and safety for ragweed pollen allergy [109-111]. At the mo- 
ment, SCIT is reasonably well standardized regarding administration protocols [112], whereas protocols for SLIT are less defined. Direct comparison studies between the two administration routes would be needed to compare the two approaches $[113,114]$. One obstacle of SLIT is the low compliance. A large-scale "real-life" study conducted in 2014 comparing SCIT and SLIT compliance, revealed that overall compliance for at least 3 years of treatment is less than $50 \%$, with a better compliance within the SCIT group [115].

Taking into account that most of the ragweed allergens exist in recombinant form, they open the field for new AIT strategies based on the production of hypoallergenic variants. These variants can be generated by introducing mutations and deletions around the B-cell epitope (IgE binding) areas, fragmentation, oligomerization, or fusion of allergen variants (chimeras). These recombinant proteins should not be IgE reactive but still be immunogenic, in order to allow higher dose administration without inducing side effects in comparison to wild-type molecules [105]. These candidates are able to replace allergen extracts and can be produced in unlimited amounts, with highly standardized quality and exact physicochemical and immunological characteristics. Products based on recombinant hypoallergens are currently under development and others have already been evaluated in phase II and III clinical trials [116-118].

An innovative approach in ragweed pollen AIT could be the development of hypoallergenic derivatives based on allergen-derived peptides reassembled into protein constructs [119] or the combination of a carrier molecule with these peptides, which will provide enhanced stability and immunogenicity, without IgE reactivity [120]. Promising results have been attained with these carrier molecules, among which are bacteriophage $\mathrm{Qb}$-derived virus-like particles [121], hepatitis B virus pre-S protein [122-124], and polyethylene glycol [125].

Some attempts have been made to find novel candidates for a therapeutic approach in ragweed allergy. A recent study generated and preclinically characterized the immunogenic domains of Amb a 1 and Art v 6, envisaging their use for immunotherapy. The study revealed that preservation of T-cell epitopes together with deletion of IgE reactive areas of Amb a 1 and Art v 6 can modulate the immunologic characteristics of the allergen, a property that makes the new molecules suitable candidates for AIT [126].

It has been hypothesized that the T-cell epitopes presented by HLA-DP or HLA-DQ molecules, as is the case with Amb a 1, might sensitize a large part of the population [127]. The use of allergens combined with TLR li- gands, which modifies the activity of antigen-presenting cells, has been proposed as a new approach for shifting from a Th2-polarized towards Th1-oriented immune response pattern [128]. Amb a 1-immunostimulatory phosphorothioate oligonucleotide conjugates have been produced. This conjugate contains a short synthetic DNA sequence that binds to TLR9 on plasmacytoid dendritic cells, thereby activating the innate immune system. This product has shown good short-term and long-term effects in subjects with moderate-severe ragweed pollen allergy, presenting low allergenicity and inducing an enhanced Th1-type response. The effects persisted for up to 2 consecutive seasons, after an administration protocol that included 6 injections only [129].

Another ragweed pollen AIT approach used an ultrashort treatment protocol in order to administer an allergoid coupled with a TLR4 agonist, monophosphoryl lipid $\mathrm{A}$, which acts as an adjuvant. This product has been shown to be safe and it induced a significant improvement in the symptom score [100]. Until now only a few clinical trials with ragweed AIT have been performed in Europe. The most recent one investigated the efficacy of SLIT with Amb a 1 as a tablet, while the others were designed for evaluation of the efficacy and safety of ragweed allergoids or extracts, either for SCIT or for SLIT (Table 3) [130].

The INSPIRED research project (http://inspired.oncogen.ro/en/at-a-glance/) has been launched in Timisoara, Romania, in an attempt to characterize all ragweed allergens in more detail by using recombinant ragweed allergens, especially regarding their clinical relevance, which is information that is still missing and urgently needed. The results from the identification of clinically important allergens and expression of these recombinant allergens will be used for the development of serological tests, which should be more accurate than the current tests. Based on these results, the project also intends to develop quantitative tests for environmental measurement of ragweed allergen load in order to develop preventive measures (Fig. 5). Another aim of the INSPIRED project is the identification of IgE epitopes of the ragweed pollen allergens. This knowledge can be the basis for novel and better forms of ragweed pollen AIT, a concept comparable with the BM32 for grass pollen allergy [131-134].

\section{Costs of Ragweed Allergy Therapy}

As has been shown for all types of immunotherapeutics, the costs of ragweed AIT can be substantial. When it comes to the two main types of therapeutics - symptom-
Chen/Marusciac/Tamas/Valenta/

Panaitescu 


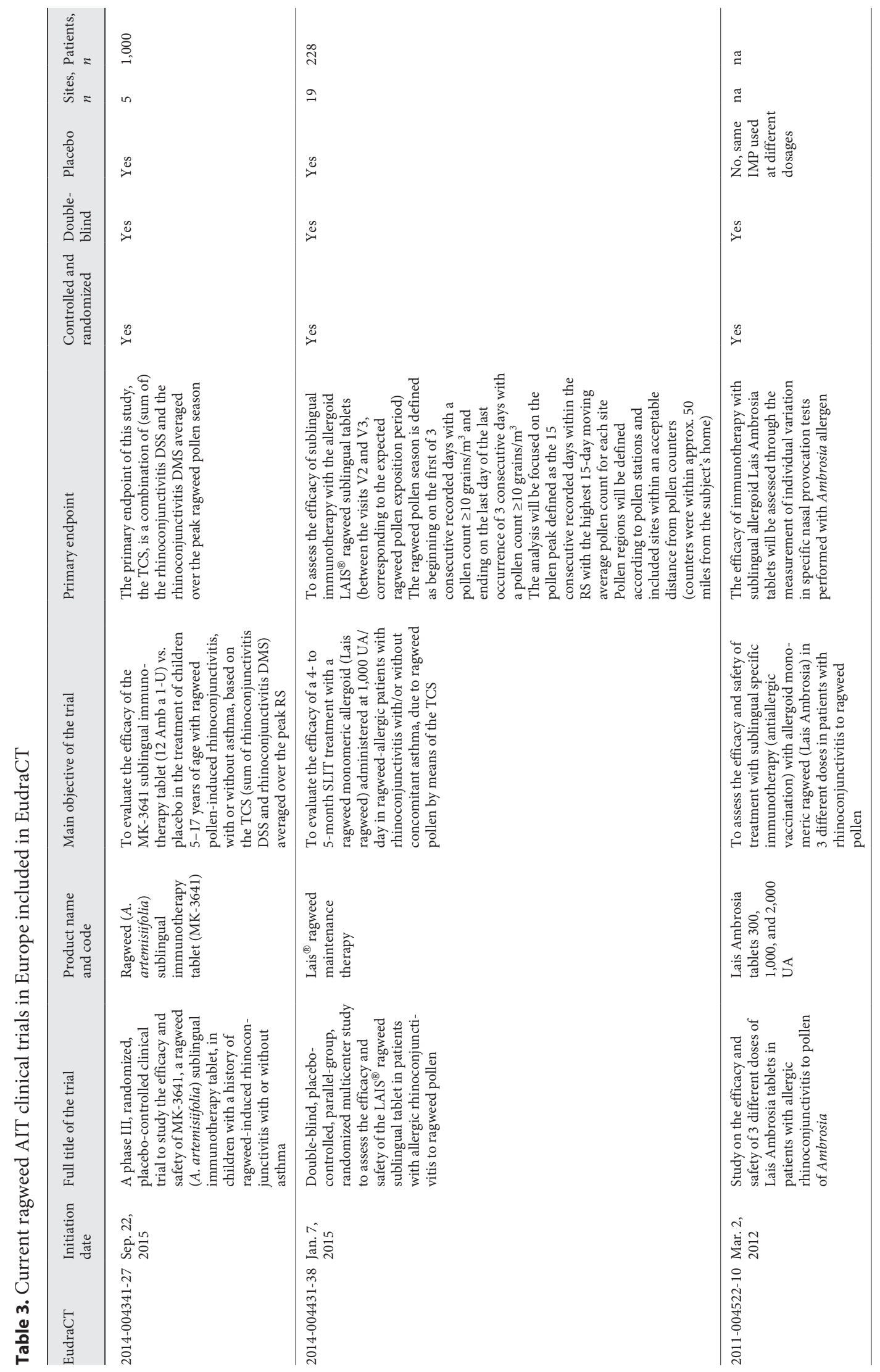




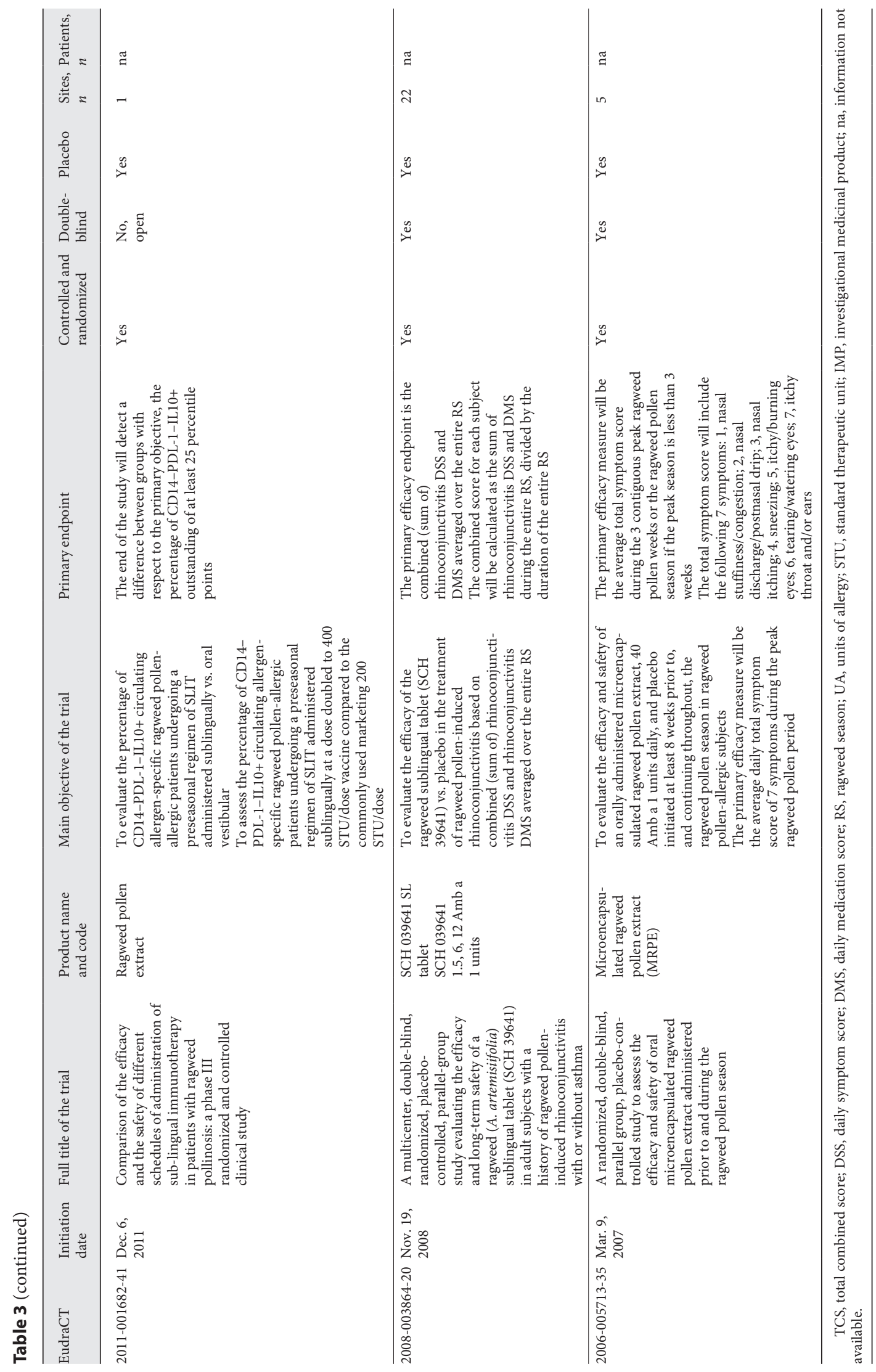


Fig. 5. Overview of the INSPIRED project. The project aim is to characterize all ragweed allergens in more detail which will have an effect on allergy prevention, fundamental research, allergy diagnosis, and finally allergy therapy.

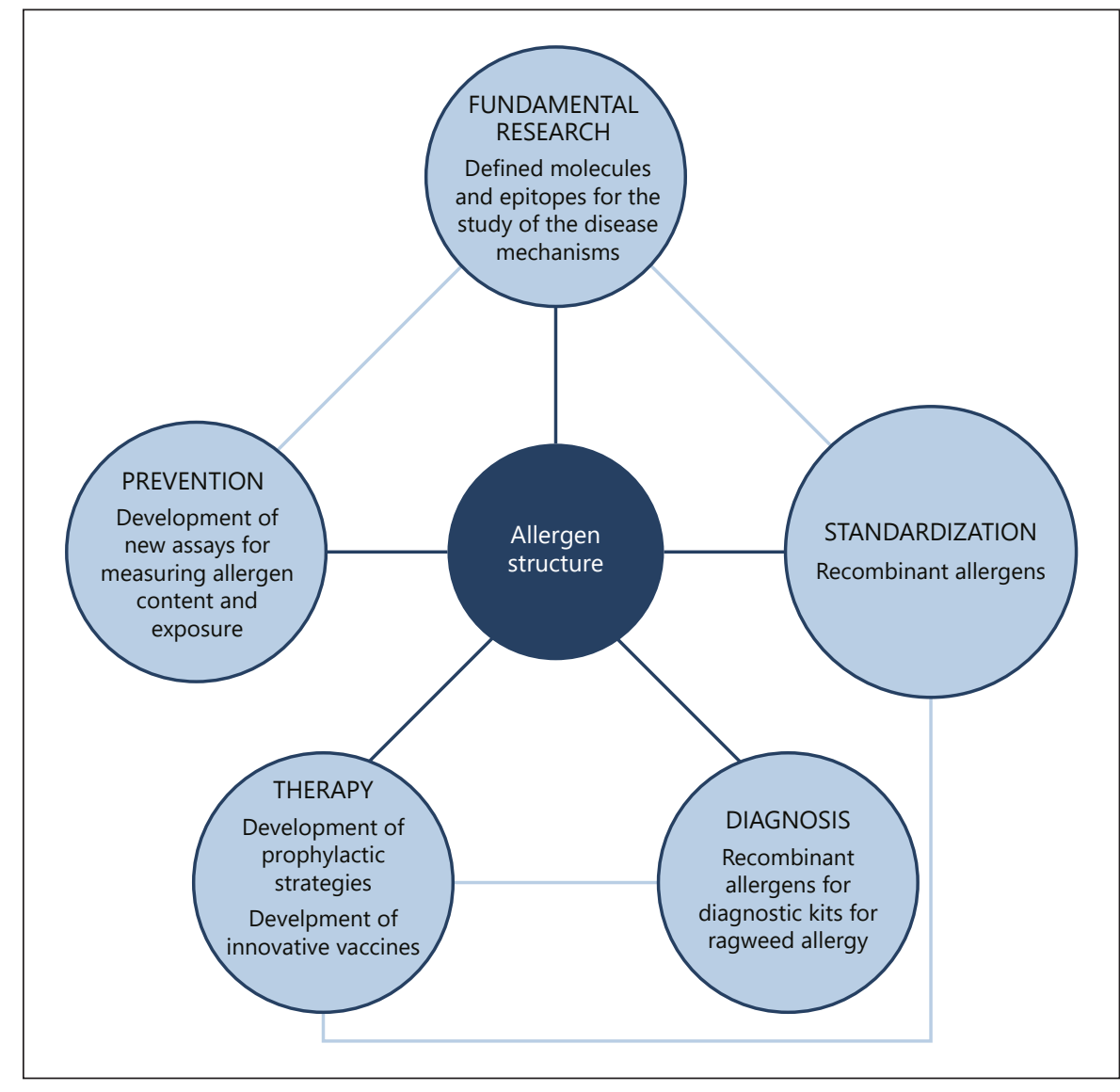

atic or immunotherapy - symptomatic treatment may be cheaper per dose, but it is usually required every day during the time of allergen exposure, whereas AIT can be more expensive in the short-term, but it is not required daily and, moreover, after completing the treatment it provides long-term protection.

Besides the medication costs, there are other expenses associated with ragweed pollen allergy, such as doctor's visits, admittance into hospital, sick leave, or devices for limiting pollen exposure. A European survey provided data regarding the considerable treatment costs for ragweed pollen allergy in different countries (Table 4) [135].

Medication costs may change in the future as new, more effective drugs are created and introduced onto the market, or as patents run out. Cost evolution is difficult to predict because the innovative drugs released on the market may be expensive, but on the other hand the increased effectiveness may reduce future health costs of ragweed pollen-induced allergy.

When establishing cost-effectiveness, several aspects should be taken into consideration, including the efficacy
Table 4. Treatment costs for ragweed allergy in Europe [135]

\begin{tabular}{lll}
\hline Country & Cost per patient, EUR & $\begin{array}{l}\text { Total cost per year, } \\
\text { EUR }\end{array}$ \\
\hline $\begin{array}{lll}\text { Austria } \\
\text { Czech Republic }\end{array}$ & $\begin{array}{l}6.3 \text { (antihistamines) } \\
\text { 43.5 (AIT) }\end{array}$ & $\begin{array}{l}88 \text { million } \\
\text { Not available }\end{array}$ \\
Germany & 650 & $17-47$ million \\
Hungary & Not available & 100 million \\
Switzerland & 24 (antihistamines) & $8-24$ million \\
Italy & $484-645$ (AIT) & 1.74 million \\
Serbia & Not available & Not available \\
France & $547-2,555$ & Not available \\
UK & $26-386$ reimbursement & Not available \\
\hline & 3,030 over 10 years &
\end{tabular}

of symptom relief during the first years of therapy, sustained efficacy and disease modification treatment outcomes, and sustained lack of symptoms after discontinuation of therapy. The practitioner has to balance between 
the level of evidence and the risk-benefit ratio when choosing a certain AIT product, as the primary concerns should be the patient's quality of life and long-term effects of the drug [87].

\section{Conclusion}

A. artemisiifolia, also known as common or short ragweed, is an invasive and noxious herbaceous plant that exists worldwide. Climate change and urbanization are key factors behind an accelerated spread of ragweed, which in turn will also increase the ragweed-related burden in many areas. Ragweed pollen allergy will become a serious healthcare problem exerting a strong negative impact on the quality of life of allergic patients. Currently, 11 ragweed allergens have been described and characterized, but in many cases information about their clinical relevance is missing. Therefore, precise diagnosis and effective treatment are not yet established for ragweed pollen allergy. There are therapeutic options for symptomatic treatment, but in many patients they cannot achieve total symptom control.
Currently, diagnosis as well as AIT, which represents the only treatment that can alter the natural course of the allergic disease, are mainly based on ragweed pollen extracts and they have their limits regarding precision in diagnosis and efficacy in treatment. Innovative strategies for ragweed AIT are under development but no promising candidates are present. Therefore, more efforts have to be invested in this field. Thus the INSPIRED research project was launched at the Center for Gene- and Cellular Therapies in the Treatment of Cancer (OncoGen, www. oncogen.ro) in Timisoara, Romania, in order to produce recombinant ragweed allergens for the component resolved diagnosis and also to find new and innovative treatment strategies.

\section{Disclosure Statement}

Rudolf Valenta has received research grants from Biomay AG, Vienna, Austria and Viravaxx, Vienna, Austria. He is a consultant for Biomay AG and Viravaxx. The other authors have no conflicts of interest to declare.

\section{References}

1 Essl F, Biró K, Brandes D, Broennimann O, Bullock JM, Chapman DS, Chauvel B, Dullinger S, Fumanal B, Guisan A, Karrer G, Kazinczi G, Kueffer C, Laitung B, Lavoie C, Leitner M, Mang T, Moser D, Müller-Schärer H, Petitpierre B, Richter R, Schaffner U, Smith M, Starfinger U, Vautard R, Vogl G, von der Lippe M, Follak S: Biological flora of the British Isles: Ambrosia artemisiifolia. J Ecol 2015; 103:1069-1098.

2 Chauvel B, Dessaint F, Cardinal-Legrand C, Bretagnolle F: The historical spread of Ambrosia artemisiifolia L. in France from herbarium records. J Biogeogr 2006;33:665-673.

-3 Storkey J, Stratonovitch P, Chapman DS, Vidotto F, Semenov MA: A process-based approach to predicting the effect of climate change on the distribution of an invasive allergenic plant in Europe. PLoS One 2014; 9:e88156.

-4 Thibaudon M, Šikoparija B, Oliver G, Smith M, Skjøth CA: Ragweed pollen source inventory for France - the second largest centre of Ambrosia in Europe. Atmos Environ 2014;83: 62-71.

5 Cecchi L, Malaspina TT, Albertini R, Zanca M, Ridolo E, Usberti I, Morabito M, Dall' Aglio P, Orlandini S: The contribution of long-distance transport to the presence of Ambrosia pollen in central Northern Italy. Aerobiologia 2007;23:145-151.
6 de Weger LA, Pashley CH, Sikoparija B, Skjoth CA, Kasprzyk I, Grewling L, Thibaudon M, Magyar D, Smith M: The long distance transport of airborne Ambrosia pollen to the UK and the Netherlands from central and south Europe. Int J Biometeorol 2016;60:1829-1839.

7 Prank M, Chapman DS, Bullock JM, Belmonte J, Berger U, Dahl A, Jager S, Kovtunenko I, Magyar D, Niemela S, Rantio-Lehtimaki A, Rodinkova V, Sauliene I, Severova E, Sikoparija B, Sofiev M: An operational model for forecasting ragweed pollen release and dispersion in Europe. Agr Forest Meteorol 2013;182:4353.

8 Gaudeul M, Giraud T, Kiss L, Shykoff JA: Nuclear and chloroplast microsatellites show multiple introductions in the worldwide invasion history of common ragweed, Ambrosia artemisiifolia. PLoS One 2011;6:e17658.

$\checkmark 9$ Weinstein I, Fletcher AH: Essentials for the control of ragweed. Am J Public Health Nations Health 1948;38:664-669.

10 Gergen PJ, Arbes SJ Jr, Calatroni A, Mitchell HE, Zeldin DC: Total IgE levels and asthma prevalence in the US population: results from the national health and nutrition examination survey 2005-2006. J Allergy Clin Immunol 2009;124:447-453.
11 Arbes SJ Jr, Gergen PJ, Elliott L, Zeldin DC: Prevalences of positive skin test responses to 10 common allergens in the us population: results from the third national health and nutrition examination survey. J Allergy Clin Immunol 2005;116:377-383.

12 Horak F, Jäger S, Türk R: Ragweed pollen allergy in Austria; in Ring J, Burg G (eds): New Trends in Allergy. Berlin, Springer, 1981, pp 175-177.

13 Jäger S: Ragweed (Ambrosia) sensitisation rates correlate with the amount of inhaled airborne pollen: a 14-year study in Vienna, Austria. Aerobiologia 2000;16:149-153.

14 Burbach GJ, Heinzerling LM, Rohnelt C, Bergmann KC, Behrendt $\mathrm{H}$, Zuberbier T: Ragweed sensitization in Europe - GA2 LEN study suggests increasing prevalence. Allergy 2009;64:664-665.

15 Thibaudon M, Hamberger C, Guilloux L, Massot R: Ragweed pollen in France: origin, diffusion, exposure. Eur Ann Allergy Clin Immunol 2010;42:209-215.

16 Tosi A, Wuthrich B, Bonini M, PietragallaKohler B: Time lag between Ambrosia sensitisation and Ambrosia allergy: a 20-year study (1989-2008) in Legnano, northern Italy. Swiss Med Wkly 2011;141:w13253. 
$>17$ Bousquet PJ, Chinn S, Janson C, Kogevinas $\mathrm{M}$, Burney P, Jarvis D: Geographical variation in the prevalence of positive skin tests to environmental aeroallergens in the European Community Respiratory Health Survey I. Allergy 2007;62:301-309.

- 18 Pichler U, Hauser M, Wolf M, Bernardi ML, Gadermaier G, Weiss R, Ebner C, Yokoi H, Takai T, Didierlaurent A, Rafaiani C, Briza P, Mari A, Behrendt H, Wallner M, Ferreira F: Pectate lyase pollen allergens: sensitization profiles and cross-reactivity pattern. PLoS One 2015;10:e0120038.

-19 Kim JH, Oh JW, Lee HB, Kim SW, Kang IJ, Kook MH, Kim BS, Park KS, Baek HS, Kim KR, Choi YJ: Changes in sensitization rate to weed allergens in children with increased weeds pollen counts in Seoul metropolitan area. J Korean Med Sci 2012;27:350-355.

20 Li J, Sun B, Huang Y, Lin X, Zhao D, Tan G, Wu J, Zhao H, Cao L, Zhong N; China Alliance of Research on Respiratory Allergic Disease: A multicentre study assessing the prevalence of sensitizations in patients with asthma and/or rhinitis in china. Allergy 2009;64: 1083-1092.

21 Fumanal B, Chauvel B, Bretagnolle F: Estimation of pollen and seed production of common ragweed in France. Ann Agric Environ Med 2007;14:233-236.

22 Emberlin J: The effects of patterns in climate and pollen abundance on allergy. Allergy 1994;49:15-20.

-23 DellaValle CT, Triche EW, Leaderer BP, Bell ML: Effects of ambient pollen concentrations on frequency and severity of asthma symptoms among asthmatic children. Epidemiology 2012;23:55-63.

24 Kasprzyk I: Non-native Ambrosia pollen in the atmosphere of Rzeszow (SE Poland); evaluation of the effect of weather conditions on daily concentrations and starting dates of the pollen season. Int J Biometeorol 2008;52:341-351.

$\checkmark 25$ Cecchi L, Morabito M, Paola Domeneghetti M, Crisci A, Onorari M, Orlandini S: Long distance transport of ragweed pollen as a potential cause of allergy in central Italy. Ann Allergy Asthma Immunol 2006;96:86-91.

26 Sommer J, Smith M, Sikoparija B, Kasprzyk I, Myszkowska D, Grewling L, Skjoth CA: Risk of exposure to airborne ambrosia pollen from local and distant sources in Europe - an example from Denmark. Ann Agric Environ Med 2015;22:625-631.

$\checkmark 27$ Asero R: Ragweed allergy in northern Italy: are patterns of sensitization changing? Eur Ann Allergy Clin Immunol 2012;44:157-159.

-28 Corsico R, Falagiani P, Ariano R, Berra D, Biale C, Bonifazi F, Campi P, Feliziani V, Frenguelli G, Galimberti M, Gallesio MT, Liccardi G, Loreti A, Marcer G, Marcucci F, Meriggi A, Minelli M, Nardelli R, Nardi G, Negrini CA, Papa G, Piu G, Pozzan M, D’Ambrosio FP, Riva G: An epidemiological survey on the allergological importance of some emerging pollens in Italy. J Investig Allergol Clin Immunol 2000;10:155-161.
29 Smiljanic K, Apostolovic D, Trifunovic S, Ognjenovic J, Perusko M, Mihajlovic L, Burazer L, van Hage M, Cirkovic Velickovic T: Subpollen particles are rich carriers of major short ragweed allergens and nadh dehydrogenases: quantitative proteomic and allergomic study. Clin Exp Allergy 2017;47:815-828.

30 Boldogh I, Bacsi A, Choudhury BK, Dharajiya N, Alam R, Hazra TK, Mitra S, Goldblum RM, Sur S: ROS generated by pollen NADPH oxidase provide a signal that augments antigeninduced allergic airway inflammation. J Clin Invest 2005;115:2169-2179.

31 Gunawan H, Takai T, Ikeda S, Okumura K, Ogawa H: Protease activity of allergenic pollen of cedar, cypress, juniper, birch and ragweed. Allergol Int 2008;57:83-91.

32 Ghiani A, Ciappetta S, Gentili R, Asero R, Citterio $S$ : Is ragweed pollen allergenicity governed by environmental conditions during plant growth and flowering? Sci Rep 2016;6: 30438.

33 Singer BD, Ziska LH, Frenz DA, Gebhard DE, Straka JG: Increasing Amb a 1 content in common ragweed (Ambrosia artemisiifolia) pollen as a function of rising atmospheric $\mathrm{CO}_{2}$ concentration. Funct Plant Biol 2005;32: 667-670.

34 Ziska LH, Gebhard DE, Frenz DA, Faulkner S, Singer BD, Straka JG: Cities as harbingers of climate change: common ragweed, urbanization, and public health. J Allergy Clin Immunol 2003;111:290-295.

35 Lake IR, Jones NR, Agnew M, Goodess CM, Giorgi F, Hamaoui-Laguel L, Semenov MA, Solomon F, Storkey J, Vautard R, Epstein MM: Climate change and future pollen allergy in Europe. Environ Health Perspect 2017; 125:385-391.

36 Scalone R, Lemke A, Stefanic E, Kolseth AK, Rasic S, Andersson L: Phenological variation in Ambrosia artemisiifolia L. facilitates near future establishment at northern latitudes. PLoS One 2016;11:e0166510.

37 WHO/IUIS Allergen Nomenclature SubCommittee: Allergen nomenclature. IUIS database. www.allergen.org.

38 El Kelish A, Zhao F, Heller W, Durner J, Winkler JB, Behrendt $\mathrm{H}$, Traidl-Hoffmann $\mathrm{C}$, Horres R, Pfeifer M, Frank U, Ernst D: Ragweed (Ambrosia artemisiifolia) pollen allergenicity: supersage transcriptomic analysis upon elevated $\mathrm{CO}_{2}$ and drought stress. BMC Plant Biol 2014;14:176.

39 King TP, Norman PS, Connell JT: Isolation and characterization of allergens from ragweed pollen. II. Biochemistry 1964;3:458468.

40 King TP, Alagon A, Kochoumian L, Kuan J, Sobotka A, Lichtenstein LM: Limited proteolysis of antigens $\mathrm{E}$ and $\mathrm{K}$ from ragweed pollen. Arch Biochem Biophys 1981;212:127135.
41 Wopfner N, Jahn-Schmid B, Schmidt G, Christ T, Hubinger G, Briza P, Radauer C, Bohle B, Vogel L, Ebner C, Asero R, Ferreira F, Schwarzenbacher R: The alpha and beta subchain of Amb a 1, the major ragweed-pollen allergen show divergent reactivity at the IgE and T-cell level. Mol Immunol 2009;46: 2090-2097.

42 Wolf M, Twaroch TE, Huber S, Reithofer M, Steiner M, Aglas L, Hauser M, Aloisi I, Asam C, Hofer H, Parigiani MA, Ebner C, Bohle B, Briza P, Neubauer A, Stolz F, Jahn-Schmid B, Wallner M, Ferreira F: Amb a 1 isoforms: unequal siblings with distinct immunological features. Allergy 2017;72:1874-1882.

43 Czerwinski EW, Midoro-Horiuti T, White MA, Brooks EG, Goldblum RM: Crystal structure of Jun a 1, the major cedar pollen allergen from Juniperus ashei, reveals a parallel $\beta$-helical core. J Biol Chem 2005;280:37403746.

44 Zhao F, Elkelish A, Durner J, Lindermayr C, Winkler JB, Rusmall io RF, Behrendt $\mathrm{H}$, Traidl-Hoffmann C, Holzinger A, Kofler W, Braun P, von Toerne C, Hauck SM, Ernst D, Frank U: Common ragweed (Ambrosia artemisiifolia L.): allergenicity and molecular characterization of pollen after plant exposure to elevated $\mathrm{NO}_{2}$. Plant Cell Environ 2016; 39:147-164.

45 Atis S, Tutluoglu B, Sahin K, Yaman M, Kucukusta AR, Oktay I: Sensitization to sunflower pollen and lung functions in sunflower processing workers. Allergy 2002;57:35-39.

46 Ghosh N, Sircar G, Saha B, Pandey N, Gupta Bhattacharya S: Search for allergens from the pollen proteome of sunflower (Helianthus annuus L.): a major sensitizer for respiratory allergy patients. PLoS One 2015;10:e0138992.

47 Asero R, Bellotto E, Ghiani A, Aina R, Villalta D, Citterio S: Concomitant sensitization to ragweed and mugwort pollen: who is who in clinical allergy? Ann Allergy Asthma Immunol 2014;113:307-313.

48 Jahn-Schmid B, Hauser M, Wopfner N, Briza P, Berger UE, Asero R, Ebner C, Ferreira F, Bohle B: Humoral and cellular cross-reactivity between Amb a 1, the major ragweed pollen allergen, and its mugwort homolog Art v 6. J Immunol 2012;188:1559-1567.

49 Pham J, Oseroff C, Hinz D, Sidney J, Paul S, Greenbaum J, Vita R, Phillips E, Mallal S, Peters B, Sette A: Sequence conservation predicts $\mathrm{T}$ cell reactivity against ragweed allergens. Clin Exp Allergy 2016;46:1194-1205.

50 Wopfner N, Bauer R, Thalhamer J, Ferreira F, Chapman M: Immunologic analysis of monoclonal and immunoglobulin E antibody epitopes on natural and recombinant Amb a 1. Clin Exp Allergy 2008;38:219-226.

51 Rogers BL, Morgenstern JP, Griffith IJ, Yu XB, Counsell CM, Brauer AW, King TP, Garman RD, Kuo MC: Complete sequence of the allergen Amb alpha II: recombinant expression and reactivity with $\mathrm{T}$ cells from ragweed allergic patients. J Immunol 1991;147:25472552.
Ragweed Pollen Allergy: An Increasing Health Issue in Europe 
52 Bouley J, Groeme R, Le Mignon M, Jain K, Chabre H, Bordas-Le Floch V, Couret MN, Bussieres L, Lautrette A, Naveau M, BaronBodo V, Lombardi V, Mascarell L, Batard T, Nony E, Moingeon P: Identification of the cysteine protease Amb a 11 as a novel major allergen from short ragweed. J Allergy Clin Immunol 2015;136:1055-1064.

53 Groeme R, Airouche S, Kopecny D, Jaekel J, Savko M, Berjont N, Bussieres L, Le Mignon $\mathrm{M}$, Jagic F, Zieglmayer P, Baron-Bodo V, Bordas-Le Floch V, Mascarell L, Briozzo P, Moingeon P: Structural and functional characterization of the major allergen Amb a 11 from short ragweed pollen. J Biol Chem 2016;291: 13076-13087.

54 Lambrecht BN, Hammad H: Allergens and the airway epithelium response: gateway to allergic sensitization. J Allergy Clin Immunol 2014;134:499-507.

55 Tao AL, He SH: Bridging PCR and partially overlapping primers for novel allergen gene cloning and expression insert decoration. World J Gastroenterol 2004;10:2103-2108.

-56 Wopfner N, Gruber P, Wallner M, Briza P, Ebner C, Mari A, Richter K, Vogel L, Ferreira F: Molecular and immunological characterization of novel weed pollen pan-allergens. Allergy 2008;63:872-881.

-57 Kandasamy MK, Burgos-Rivera B, McKinney EC, Ruzicka DR, Meagher RB: Class-specific interaction of profilin and ADF isovariants with actin in the regulation of plant development. Plant Cell 2007;19:3111-3126.

58 Valenta R, Duchene M, Pettenburger K, Sillaber C, Valent P, Bettelheim P, Breitenbach M, Rumpold H, Kraft D, Scheiner O: Identification of profilin as a novel pollen allergen; $\mathrm{IgE}$ autoreactivity in sensitized individuals. Science 1991;253:557-560.

-59 Valenta R, Duchene M, Ebner C, Valent P, Sillaber C, Deviller P, Ferreira F, Tejkl M, Edelmann H, Kraft D, et al: Profilins constitute a novel family of functional plant pan-allergens. J Exp Med 1992;175:377-385.

-60 Valenta R, Ferreira F, Grote M, Swoboda I, Vrtala S, Duchene M, Deviller P, Meagher RB, McKinney E, Heberle-Bors E, et al: Identification of profilin as an actin-binding protein in higher plants. J Biol Chem 1993;268:2277722781.

-61 Offermann LR, Schlachter CR, Perdue ML, Majorek KA, He JZ, Booth WT, Garrett J, Kowal K, Chruszcz M: Structural, functional, and immunological characterization of profilin panallergens Amb a 8, Art v 4, and Bet v 2. J Biol Chem 2016;291:15447-15459.

62 Pierson ES, Miller DD, Callaham DA, Shipley AM, Rivers BA, Cresti M, Hepler PK: Pollen tube growth is coupled to the extracellular calcium ion flux and the intracellular calcium gradient: effect of BAPTA-type buffers and hypertonic media. Plant Cell 1994;6:18151828.
63 Gadermaier G, Wopfner N, Wallner M, Egger M, Didierlaurent A, Regl G, Aberger F, Lang R, Ferreira F, Hawranek T: Array-based profiling of ragweed and mugwort pollen allergens. Allergy 2008;63:1543-1549.

64 Parody N, Fuertes MA, Alonso C, Pico de Coana Y: Analysis of calcium-induced conformational changes in calcium-binding allergens and quantitative determination of their IgE binding properties. Methods Mol Biol 2013;963:115-125.

65 Roebber M, Hussain R, Klapper DG, Marsh DG: Isolation and properties of a new short ragweed pollen allergen, Ra6. J Immunol 1983;131:706-711.

66 Hiller KM, Lubahn BC, Klapper DG: Cloning and expression of ragweed allergen Amb a 6. Scand J Immunol 1998;48:26-36.

67 Morales M, Lopez-Matas MA, Moya R, Carnes J: Cross-reactivity among non-specific lipidtransfer proteins from food and pollen allergenic sources. Food Chem 2014;165:397-402.

68 Klapper DG, Goodfriend L, Capra JD: Amino acid sequence of ragweed allergen Ra3. Biochemistry 1980;19:5729-5734.

69 Adolphson C, Goodfriend L, Gleich GJ: Reactivity of ragweed allergens with $\mathrm{IgE}$ antibodies: analyses by leukocyte histamine release and the radioallergosorbent test and determination of cross-reactivity. J Allergy Clin Immunol 1978;62:197-210.

70 Roebber M, Marsh DG: Isolation and characterization of allergen Amb a VII from short ragweed pollen. J Allergy Clin Immunol 1991; $87: 324$.

71 Leonard R, Wopfner N, Pabst M, Stadlmann J, Petersen BO, Duus JO, Himly M, Radauer C, Gadermaier G, Razzazi-Fazeli E, Ferreira F, Altmann F: A new allergen from ragweed (Ambrosia artemisiifolia) with homology to Art v 1 from mugwort. J Biol Chem 2010;285: 27192-27200.

72 Pablos I, Eichhorn S, Machado Y, Briza P, Neunkirchner A, Jahn-Schmid B, Wildner S, Soh WT, Ebner C, Park JW, Pickl WF, Arora N, Vieths S, Ferreira F, Gadermaier G: Distinct epitope structures of defensin-like proteins linked to proline-rich regions give rise to differences in their allergenic activity. Allergy 2018;73:431-441.

73 Lapkoff CB, Goodfriend L: Isolation of a low molecular weight ragweed pollen allergen: Ra5. Int Arch Allergy Appl Immunol 1974;46: 215-229.

74 Mole LE, Goodfriend L, Lapkoff CB, Kehoe JM, Capra JD: The amino acid sequence of ragweed pollen allergen Ra5. Biochemistry 1975;14:1216-1220.

75 Roebber M, Klapper DG, Marsh DG: Two isoallergens of short ragweed component Ra5. J Immunol 1982;129:120-125.

76 Metzler WJ, Valentine K, Roebber M, Marsh DG, Mueller L: Proton resonance assignments and three-dimensional solution structure of the ragweed allergen Amb a v by nuclear magnetic resonance spectroscopy. Biochemistry 1992;31:8697-8705.
77 Bordas-Le Floch V, Le Mignon M, Bouley J, Groeme R, Jain K, Baron-Bodo V, Nony E, Mascarell L, Moingeon P: Identification of novel short ragweed pollen allergens using combined transcriptomic and immunoproteomic approaches. PLoS One 2015; 10:e0136258.

-78 Rogers BL, Pollock J, Klapper DG, Griffith IJ: Sequence of the proteinase-inhibitor cystatin homologue from the pollen of Ambrosia artemisiifolia (short ragweed). Gene 1993;133: 219-221.

79 Popovic MM, Milovanovic M, Burazer L, Vuckovic O, Hoffmann-Sommergruber K, Knulst AC, Lindner B, Petersen A, Jankov R, Gavrovic-Jankulovic M: Cysteine proteinase inhibitor Act $\mathrm{d} 4$ is a functional allergen contributing to the clinical symptoms of kiwifruit allergy. Mol Nutr Food Res 2010;54:373-380.

80 Kanter U, Heller W, Durner J, Winkler JB, Engel $\mathrm{M}$, Behrendt $\mathrm{H}$, Holzinger A, Braun $\mathrm{P}$, Hauser M, Ferreira F, Mayer K, Pfeifer M, Ernst D: Molecular and immunological characterization of ragweed (Ambrosia artemisiifolia L.) pollen after exposure of the plants to elevated ozone over a whole growing season. PLoS One 2013;8:e61518.

81 Karrer G: Control of common ragweed by mowing and hoeing. Quedlinburg, JuliusKühn-Archiv, 2016. https://doi.org/10.5073/ jka.2016.455.23.

82 Global Initiative for Asthma: Global strategy for asthma management and prevention. 2017. www.ginasthma.org.

83 Barchuk WT, Salapatek AM, Ge T, D’Angelo P, Liu X: A proof-of-concept study of the effect of a novel H3-receptor antagonist in allergen-induced nasal congestion. J Allergy Clin Immunol 2013;132:838-846.e6.

-84 Stebbins KJ, Broadhead AR, Musiyenko A, Barik S, Scott JM, Truong YP, Stearns BA, Hutchinson JH, Prasit P, Evans JF, Lorrain DS: DP2 (CRTh2) antagonism reduces ocular inflammation induced by allergen challenge and respiratory syncytial virus. Int Arch Allergy Immunol 2012;157:259-268.

85 Andoh T, Sakai K, Urashima M, Kitazawa K, Honma A, Kuraishi Y: Involvement of leukotriene B4 in itching in a mouse model of ocular allergy. Exp Eye Res 2012;98:97-103.

-86 Aryan Z, Holgate ST, Radzioch D, Rezaei N: A new era of targeting the ancient gatekeepers of the immune system: Toll-like agonists in the treatment of allergic rhinitis and asthma. Int Arch Allergy Immunol 2014;164:46-63.

87 Bachert C, Noergaard Andreasen J: Cost-effectiveness of immunotherapy in the treatment of seasonal allergic rhinitis: identifying product-specific parameters of relevance for health care decision-makers and clinicians. Int Arch Allergy Immunol 2015;168:213-217.

88 Canonica GW, Bousquet J, Mullol J, Scadding GK, Virchow JC: A survey of the burden of allergic rhinitis in Europe. Allergy 2007; 62(suppl 85):17-25. 
-89 Larsen JN, Broge L, Jacobi H: Allergy immunotherapy: the future of allergy treatment. Drug Discov Today 2016;21:26-37.

-90 Kristiansen M, Dhami S, Netuveli G, Halken S, Muraro A, Roberts G, Larenas-Linnemann D, Calderon MA, Penagos M, Du Toit G, Ansotegui IJ, Kleine-Tebbe J, Lau S, Matricardi PM, Pajno G, Papadopoulos NG, Pfaar O, Ryan D, Santos AF, Timmermanns F, Wahn U, Sheikh A: Allergen immunotherapy for the prevention of allergy: a systematic review and meta-analysis. Pediatr Allergy Immunol 2017;28:18-29.

-91 Jutel M, Agache I, Bonini S, Burks AW, Calderon M, Canonica W, Cox L, Demoly P, Frew AJ, O’Hehir R, Kleine-Tebbe J, Muraro A, Lack G, Larenas D, Levin M, Nelson H, Pawankar R, Pfaar O, van Ree R, Sampson H, Santos AF, Du Toit G, Werfel T, Gerth van Wijk R, Zhang L, Akdis CA: International consensus on allergy immunotherapy. J Allergy Clin Immunol 2015;136:556-568.

-92 Clowes GHA: A preliminary communication on the treatment of autumnal hay fever by vaccination with an aqueous extract of the pollen of ragweed. Proc Soc Exp Biol Med 1913;10:70-72.

$\checkmark 93$ Cooke RA, Barnard S, Hebald AT, Stull A: Serological evidence of immunity with coexisting sensitization in a type of human allergy, hay fever. J Exp Med 1935;62:733.

\$4 Connell JT, Sherman WB: Skin-sensitizing antibody titer. III. Relationship of the skinsensitizing antibody titer to the intracutaneous skin test, to the tolerance of injections of antigens, and to the effects of prolonged treatment with antigen. J Allergy 1964;35: 169-176.

$>95$ Lowell FC, Franklin W: A double-blind study of the effectiveness and specificity of injection therapy in ragweed hay fever. $\mathrm{N}$ Engl J Med 1965;273:675-679.

-96 Focke-Tejkl M, Valenta R: Safety of engineered allergen-specific immunotherapy vaccines. Curr Opin Allergy Clin Immunol 2012;12:555-563.

-97 Larenas-Linnemann D, Esch R, Plunkett G, Brown S, Maddox D, Barnes C, Constable D: Maintenance dosing for sublingual immunotherapy by prominent European allergen manufacturers expressed in bioequivalent allergy units. Ann Allergy Asthma Immunol 2011;107:448-458.e3.

$>98$ Warrington R: Immunotherapy in asthma. Immunotherapy 2010;2:711-725.

>99 Rosewich M, Schulze J, Eickmeier O, Telles T, Rose MA, Schubert R, Zielen S: Tolerance induction after specific immunotherapy with pollen allergoids adjuvanted by monophosphoryl lipid A in children. Clin Exp Immunol 2010;160:403-410.

-100 Patel P, Holdich T, Fischer von WeikersthalDrachenberg KJ, Huber B: Efficacy of a short course of specific immunotherapy in patients with allergic rhinoconjunctivitis to ragweed pollen. J Allergy Clin Immunol 2014;133:121-129.e2.
101 Casale TB, Stokes JR: Immunotherapy: what lies beyond. J Allergy Clin Immunol 2014; 133:612-619, quiz 620.

102 El-Qutob D: Off-label uses of omalizumab. Clin Rev Allergy Immunol 2016;50:84-96.

103 Chang TW, Shiung YY: Anti-IgE as a mast cell-stabilizing therapeutic agent. J Allergy Clin Immunol 2006;117:1203-1212, quiz 1213.

104 Casale TB, Busse WW, Kline JN, Ballas ZK, Moss MH, Townley RG, Mokhtarani M, Seyfert-Margolis V, Asare A, Bateman K, Deniz Y, Immune Tolerance Network G: Omalizumab pretreatment decreases acute reactions after rush immunotherapy for ragweed-induced seasonal allergic rhinitis. J Allergy Clin Immunol 2006;117:134-140.

105 Focke-Tejkl M, Weber M, Niespodziana K, Neubauer A, Huber H, Henning R, Stegfellner G, Maderegger B, Hauer M, Stolz F, Niederberger V, Marth K, Eckl-Dorna J, Weiss R, Thalhamer J, Blatt K, Valent P, Valenta R: Development and characterization of a recombinant, hypoallergenic, peptide-based vaccine for grass pollen allergy. J Allergy Clin Immunol 2015;135:1207-1217.e11.

106 Mosges R, Kasche EM, Raskopf E, Singh J, Sohlich L, Astvatsatourov A, Shah-Hosseini K, Pirotton S, Haazen L, Durham SR, Legon T, Zadoyan G, Shamji MH: A randomized, double-blind, placebo-controlled, dosefinding trial with Lolium perenne peptide immunotherapy. Allergy 2017, Epub ahead of print.

107 El-Qutob D, Reche P, Subiza JL, FernandezCaldas E: Peptide-based allergen specific immunotherapy for the treatment of allergic disorders. Recent Pat Inflamm Allergy Drug Discov 2015;9:16-22.

108 Quirino T, Iemoli E, Siciliani E, Parmiani S, Milazzo F: Sublingual versus injective immunotherapy in grass pollen allergic patients: a double blind (double dummy) study. Clin Exp Allergy 1996;26:1253-1261.

-109 Nayak AS, Atiee GJ, Dige E, Maloney J, Nolte H: Safety of ragweed sublingual allergy immunotherapy tablets in adults with allergic rhinoconjunctivitis. Allergy Asthma Proc 2012;33:404-410.

110 Creticos PS, Maloney J, Bernstein DI, Casale T, Kaur A, Fisher R, Liu N, Murphy K, Nekam K, Nolte H: Randomized controlled trial of a ragweed allergy immunotherapy tablet in North American and European adults. J Allergy Clin Immunol 2013;131: 1342-1349.e6.

-111 Nolte H, Amar N, Bernstein DI, Lanier BQ, Creticos P, Berman G, Kaur A, Hebert J, Maloney J: Safety and tolerability of a short ragweed sublingual immunotherapy tablet. Ann Allergy Asthma Immunol 2014;113: 93-100.e3.
112 Cox L, Nelson H, Lockey R, Calabria C, Chacko T, Finegold I, Nelson M, Weber R, Bernstein DI, Blessing-Moore J, Khan DA, Lang DM, Nicklas RA, Oppenheimer J, Portnoy JM, Randolph C, Schuller DE, Spector SL, Tilles S, Wallace D: Allergen immunotherapy: a practice parameter third update. J Allergy Clin Immunol 2011;127:S1S55.

13 Oktemer T, Altintoprak N, Muluk NB, Senturk M, Kar M, Bafaqeeh SA, Bellussi L, Passali D, Cingi C: Clinical efficacy of immunotherapy in allergic rhinitis. Am J Rhinol Allergy 2016;30(suppl 1):4-7.

114 Khinchi MS, Poulsen LK, Carat F, Andre C, Hansen AB, Malling HJ: Clinical efficacy of sublingual and subcutaneous birch pollen allergen-specific immunotherapy: a randomized, placebo-controlled, double-blind, double-dummy study. Allergy 2004;59:4553.

115 Egert-Schmidt AM, Kolbe JM, Mussler S, Thum-Oltmer S: Patients' compliance with different administration routes for allergen immunotherapy in Germany. Patient Prefer Adherence 2014;8:1475-1481.

116 Tulic MK, Fiset PO, Christodoulopoulos P, Vaillancourt P, Desrosiers M, Lavigne F, Eiden J, Hamid Q: Amb a 1-immunostimulatory oligodeoxynucleotide conjugate immunotherapy decreases the nasal inflammatory response. J Allergy Clin Immunol 2004;113: 235-241.

117 Curin M, Khaitov M, Karaulov A, Namazova-Baranova L, Campana R, Garib V, Valenta R: Next-generation of allergen-specific immunotherapies: molecular approaches. Curr Allergy Asthma Rep 2018, in press.

118 Valenta R, Karaulov A, Niederberger V, Gattinger $\mathrm{P}$, van Hage $\mathrm{M}$, Flicker S, Linhart B, Campana R, Focke-Tejkl M, Curin M, EcklDorna J, Lupinek C, Resch-Marat Y, Vrtala S, Mittermann I, Garib V, Khaitov M, Valent P, Pickl WF: Molecular aspects of allergens and allergy. Adv Immunol 2018, in press.

119 Curin M, Weber M, Thalhamer T, Swoboda I, Focke-Tejkl M, Blatt K, Valent P, Marth K, Garmatiuk T, Gronlund H, Thalhamer J, Spitzauer S, Valenta R: Hypoallergenic derivatives of Fel d 1 obtained by rational reassembly for allergy vaccination and tolerance induction. Clin Exp Allergy 2014;44:882894.

120 Valenta R, Campana R, Niederberger V: Recombinant allergy vaccines based on allergen-derived B cell epitopes. Immunol Lett 2017;189:19-26.

121 Kundig TM, Senti G, Schnetzler G, Wolf C, Prinz Vavricka BM, Fulurija A, Hennecke F, Sladko K, Jennings GT, Bachmann MF: Der $\mathrm{p} 1$ peptide on virus-like particles is safe and highly immunogenic in healthy adults. J Allergy Clin Immunol 2006;117:1470-1476.
Ragweed Pollen Allergy: An Increasing Health Issue in Europe
Int Arch Allergy Immunol DOI: $10.1159 / 000487997$ 
122 Niespodziana K, Focke-Tejkl M, Linhart B, Civaj V, Blatt K, Valent P, van Hage M, Gronlund H, Valenta R: A hypoallergenic cat vaccine based on Fel d 1-derived peptides fused to hepatitis B PreS. J Allergy Clin Immunol 2011;127:1562-1570.e6.

123 Marth K, Breyer I, Focke-Tejkl M, Blatt K, Shamji MH, Layhadi J, Gieras A, Swoboda I, Zafred D, Keller W, Valent P, Durham SR, Valenta R: A nonallergenic birch pollen allergy vaccine consisting of hepatitis PreSfused Bet $\mathrm{v} 1$ peptides focuses blocking IgG toward IgE epitopes and shifts immune responses to a tolerogenic and Th1 phenotype. J Immunol 2013;190:3068-3078.

124 Banerjee S, Weber M, Blatt K, Swoboda I, Focke-Tejkl M, Valent P, Valenta R, Vrtala S: Conversion of Der p 23, a new major house dust mite allergen, into a hypoallergenic vaccine. J Immunol 2014;192:48674875.

125 Fujimura T, Fujinami K, Ishikawa R, Tateno M, Tahara Y, Okumura Y, Ohta H, Miyazaki $\mathrm{H}$, Taniguchi M: Recombinant fusion allergens, Cry $\mathrm{j} 1$ and Cry $\mathrm{j} 2$ from Japanese cedar pollen, conjugated with polyethylene glycol potentiate the attenuation of Cry $\mathrm{j}$ 1-specific IgE production in Cry $\mathrm{j} 1$-sensitized mice and Japanese cedar pollen allergen-sensitized monkeys. Int Arch Allergy Immunol 2015;168:32-43.

126 Sancho AI, Wallner M, Hauser M, Nagl B, Himly M, Asam C, Ebner C, Jahn-Schmid B, Bohle B, Ferreira F: T cell epitope-containing domains of ragweed Amb a 1 and mugwort Art v 6 modulate immunologic responses in humans and mice. PLoS One 2017;12:e0169784.
127 Jahn-Schmid B, Wopfner N, Hubinger G, Asero R, Ebner C, Ferreira F, Bohle B: The T-cell response to Amb a 1 is characterized by 3 dominant epitopes and multiple $\mathrm{MHC}$ restriction elements. J Allergy Clin Immunol 2010;126:1068-1071.e2.

128 Asai K, Foley SC, Sumi Y, Yamauchi Y, Takeda N, Desrosiers M, Lavigne F, Hamid Q: Amb a 1-immunostimulatory oligodeoxynucleotide conjugate immunotherapy increases $\mathrm{CD} 4+\mathrm{CD} 25+\mathrm{T}$ cells in the nasal mucosa of subjects with allergic rhinitis. Allergol Int 2008;57:377-381.

129 Creticos PS, Schroeder JT, Hamilton RG, Balcer-Whaley SL, Khattignavong AP, Lindblad R, Li H, Coffman R, Seyfert V, Eiden JJ, Broide D; Immune Tolerance Network Group: Immunotherapy with a ragweedToll-like receptor 9 agonist vaccine for allergic rhinitis. N Engl J Med 2006;355:14451455.

130 European Medicines Agency: EU clinical trials register. 2017

131 Valenta R, Campana R, Focke-Tejkl M, Niederberger V: Vaccine development for allergen-specific immunotherapy based on recombinant allergens and synthetic allergen peptides: lessons from the past and novel mechanisms of action for the future. J Allergy Clin Immunol 2016;137:351-357.
132 Zieglmayer P, Focke-Tejkl M, Schmutz R, Lemell P, Zieglmayer R, Weber M, Kiss R, Blatt K, Valent P, Stolz F, Huber H, Neubauer A, Knoll A, Horak F, Henning R, Valenta R: Mechanisms, safety and efficacy of a $B$ cell epitope-based vaccine for immunotherapy of grass pollen allergy. EBioMedicine 2016;11:43-57.

133 Cornelius C, Schoneweis K, Georgi F, Weber $M$, Niederberger V, Zieglmayer P, Niespodziana $\mathrm{K}$, Trauner M, Hofer $\mathrm{H}$, Urban S, Valenta R: Immunotherapy with the PreSbased grass pollen allergy vaccine BM32 induces antibody responses protecting against hepatitis B infection. EBioMedicine 2016;11: 58-67.

134 Niederberger V, Neubauer A, Gevaert P, Zidarn $\mathrm{M}$, Worm M, Aberer W, Malling HJ, Pfaar O, Klimek L, Pfutzner W, Ring J, Darsow U, Novak N, Gerth van Wijk R, EcklDorna J, Focke-Tejkl M, Weber M, Muller HH, Klinger J, Stolz F, Breit N, Henning R, Valenta R: Safety and efficacy of immunotherapy with the recombinant B-cell epitope-based grass pollen vaccine $\mathrm{BM} 32 . \mathrm{J} \mathrm{Al}-$ lergy Clin Immunol 2018, Epub ahead of print.

135 Bullock J, Chapman D, Schafer S, Roy D, Girardello M, Haynes T, Beal S, Wheeler B, Dickie I, Phang Z: Assessing and controlling the spread and the effects of common ragweed in Europe. Final report: ENV. B2/ETU/2010/0037. 2010. http://ec.europa. eu/environment/nature/invasivealien/docs/ Final_Final_Report.pdf (accessed March 2017). 